\title{
Entreneurs Perception of the Determination of Business Location in the Village Bakpia Pathok Yogyakarta
}

\author{
Novita.WS, Vienna Artina.S, Florencia Okalira \\ Sekolah Tinggi Pariwisata Trisakti \\ Jakarta, Indonesia \\ novita.ws@stptrisakti.ac.id
}

\begin{abstract}
Bakpia is Chinese-acculturation food with the local culture. There are 85 bakpia Pathok businesses with the scope of the domestic industry and small industry. The purpose of this study is to identify the perceptions of entrepreneurs on the factors that determine business location in the village bakpia Pathok, as well as determining the location of the business based on the perceptions of entrepreneurs. This research employs descriptive method to describe the factual, and accurate phenomenon systematically researched. This research uses purposive sampling techniques. Primary data collection is conducted by observation and interviews with the chairman and the board association of bakpia entrepreneurs in May 2015 until July 2015 and distributed questionnaires to 68 entrepreneurs in May 2015. The data are obtained and tested for validity and reliability with SPSS version 20. The factors of the research are community environment (3.92), resources (natural) Other (3.81), proximity to raw material / supplier (3:57), proximity with the market (3:40), facilities and transportation costs (3:35) and labor (2.74). The most dominant factor is the environmental community while the labor factor is the lowest value.
\end{abstract}

Keywords - entrepreneurs, business location, bakpia pathok, village, and industry

\section{INTRODUCTION}

Bakpia is a form of acculturation in the culinary field that occurs between the Indonesian with the Chinese. Almost all regions in Indonesia have typical food of each region. When talking about bakpia, people will directly think to the city of Yogyakarta. Bakpia is one of food souvenirs of Yogyakarta. These flat round shaped cakes contain green beans and is a little sticky since it is made from a mixture of green beans, sugar, cooking oil and salt wrapped in a flour dough.

The center for bakpia industry is a village Pathok Ngampilan, District Ngampilan, Yogyakarta. Most of this is done in the industry bakpia small and medium-scale industries such as household industries.

The small and medium Industry are the backbone of the economy of the province. In 2005 there are around 74941 SME business units with a workforce 243313 people, compared to 2012 the number of SMEs existing business unit
81515 business units that provide employment for 300539 people (DIY Disperindagkop, 2012). In other words, the rate of growth of SMEs during the period 2005-2012 reached more than 8.7 per cent for the number of business units and more than 24 percent of employment. This prove that the SME sector is still the mainstay of the economy of the province.

There are factors that support the consideration of entrepreneurs in establishing a business, one of them is the location factor.

Pathok village is located 300 meters west of Malioboro street, precisely at AIP KS.Tumbun street in Sub Ngampilan, District Ngampilan, Yogyakarta. AIP KS.Tumbun along the way can be found a wide variety of brand bakpia which is always crowded with tourists who want to buy special food of Yogyakarta. According Lurah Ngampilan, Maryuni, in an interview with the daily newspaper Republika (Wednesday, November 27, 2013) said that there were at least 120 brands bakpia Pathok in the village, as well as three community bakpia in Pathok, one of whom has become a cooperative of craftsmen.

Based on the identification of problems that have been mentioned, the problems can be formulated as follows:

a. Why does bakpia Pathok business entrepreuneur choose the location in Ngampilan village Yogyakarta?

b. What is the dominant factor which has the highest value in determining business location in bakpia Pathok village, Ngampilan, Yogyakarta?

The purpose of the research is to be achieved:

a. To determine the factors that affect entrepreneurs determine business location in the village bakpia Pathok.

b. To determine the most dominant factor that has the highest value for entrepreneurs in determining business location in the village bakpia Pathok. 


\section{LITERATURE REVIEW}

\section{Understanding of Perceptions}

Perception is the observation of objects, events or relationships obtained by concluding information and interpret the message. (Rachmat, 2007: 51). Perception is an active process. Everyone pay attention, organize, and interpret all experiences selectively.

\section{Terms of occurrence of Perception}

According to Sunaryo (2004: 98) the terms of the perception is as follows:

a. The existence of a perceived object

b. Their attention is the first step as a preparation in the perceptual.

c. Their sense organs / receptors which means to receive a stimulus

d. Sensory nerves as a tool to continue the stimulus to the brain, which then as a tool to organize the response.

\section{Factors Influencing Perceptions}

According Walgito (2004: 89), there are several factors that play a role in influencing the perception among others:

a. Objects are perceived

Objects raises the stimulus that the sensory organs or receptor. Stimulus could come from outside the individual who perceives, but it can also come from within the individual in question is directly on the nerve receiver that works as a receptor, however, most of the stimulus coming from outside the individual.

b. Sense organ, terms, and central nervous system.

Sense organ or receptor is a tool for receiving the stimulus received to nervous system receptors, namely the brain. Necessary tools to conduct nerve motor response.

c. Attention

To realize the required perception or hold their attention, which is the first step as a preparation to hold on. The concentration of all individual activities shown to something or set of objects.

In urban areas, competition for land is very strong, especially in the central part of the city because of the region are favorable locations, in addition to the ground there are generally rare. For this reason the price of land in the downtown area is very expensive. The more distant location from the city center, decreasing demand for land and if there is planty of land, then the lease offered to pay people in meter square of land declined to follow the distance.

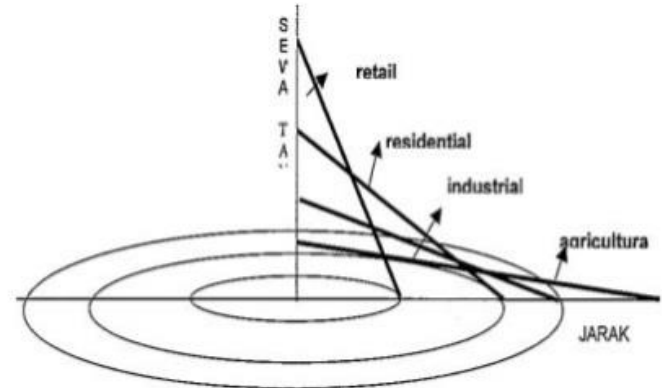

Fig. 1. Teori Rent

Rent of the theory can be seen that the distance factor is what determines the location of trading activity.

Central places theory was developed by Christaller (1933) and Losch (1954), which formulates hierarchical patterns of relatedness space center. Christaller explained his theory about the spread and size of settlements that can be explained by the function of his ministry with its approach in economics applied to the retail trade facilities, with two basic concepts of the theory are:

a. The threshold or thresholds population market the ratio is between the population and a profitable business activity. This concept explains how a population is effective for a service / services that are affected by the following factors: the level of demand of goods, quality, durability of goods and shopping frequency.

b. The threshold distance which is a measure that can be tolerated within the population to obtain goods and services. Explaining how far the maximum distance to acquire goods and services.

From central place theory can be seen that the hierarchy of trade activities are supported by the local population and certain services. The deciding factor trading location of each hierarchy is a big trade and type of goods sold at each trading facilities, the number of supporters and the area of services. Besides the distance factor is an important determinant of trade activity location.
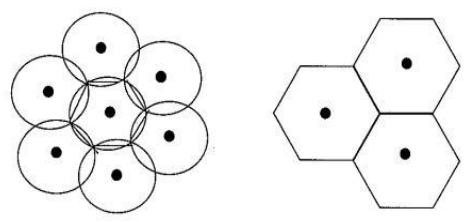

Fig. 2. Market Area Model Hexagonal Christaller

Sin (1982) divides the city center trade analysis on the factors that influence accessibility and spatial linkages. Ease of accessibility with regard to the achievement of a location through public and private vehicles and pedestrians, which can be measured by the density of traffic, the number of public transport, private vehicles and circulation patterns. Understanding spatial linkages in conjunction with an activity relative position in space, which internally can be measured 
through their most functions support the development of onsite activities and externally measured through distance from other trading functions and the relative position of the trade center site to another.

The two theories that mentioned above would be a concern by the trading company in selecting the location of activity is the rental place in the central high and the desire for ease relations (accessibility) as well as spatial linkages with other activities. The effects of this high-rent place that will attract or prevent the entry of the company and encourages agglomeration for certain types.

\section{Agglomeration Theory and Aspects Proximity (proximility)}

Aspects proximity to conduct the economic activity because of their willingness to undertake the agglomeration. Agglomeration is done because they have the economies scale is high and comparative advantage which can increase the economic activity.

Desire of economic agents make no exception for entrepreneurs bakpia to get closer to the strategic locations that have economies of scale and comparative advantage.

\section{Theory of Industrial Location}

a. Industrial Location Theory According to Von Thunen Von Thunnen developed the theory of the location in the early 19th century Thunnen observed in the area where he lives, from these observations Thunnen find a range of agricultural commodities grown according to certain patterns. Having regard to the distance between the area of production and the market, the pattern of inserting variable durability, weight and price of various agricultural commodities. The assumptions of the theory of Von Thunnen locations are as follows:

1) There is a secluded area consisting of an urban area with a hinterland which is the only regional suppliers of basic needs of agricultural commodities.

2) The urban area is an area sales of surplus production hinterland and does not accept the sale of agricultural products from other regions.

3) The interior does not sell excess production to other regions except for the urban areas.

4) The interior is homogeneous and suitable areas for crops and livestock middle plains.

5) Inland areas inhabited by farmers who are trying to gain the maximum advantage and were able to adjust crop yields and farm with the request contained in the urban areas.

6) Cart is the only transportation driven by a horse.

7) The cost of transport is borne by farmers and in proportion for the distance. Farmers sell in fresh form.

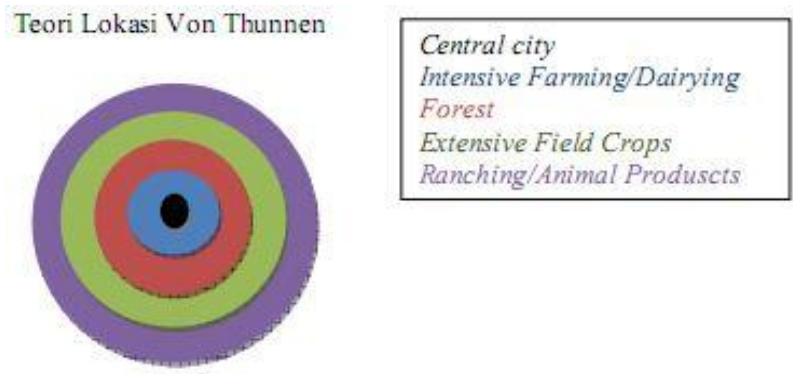

Fig. 3. Location Theory Von Thunnen

With these assumptions, the regional location of various types of agriculture will develop in a circular shape irregular surrounding agricultural areas, as in figure 3.

\section{Theory of Business Location}

The location is a store or retailer in strategic areas to maximize profits (Swastha, 2000). Selecting the location of trade is an important decision for businesses that need to entice customers to come into your place of business to fulfill their needs. The choice of location has a strategic function because it can also determine the attachment of the objectives of the enterprise.

The location will affect future growth. The selected area should be able to grow economically so that it can maintain the viability of the business. The local environment can be changed at any time, if the value of the location bad, then the business location should be moved or closed. First, choose the area where the store will be opened, which particular city, then find the location. The location is where most shops that can be seen hanging from the average number of audiences who pass the store every day, the percentage of audience who come to the store. Factors that influence the choice of location for businesses by Manullang, 2001 (in Zoeldhan, 2011) include:

a. Environment society.

b. Proximity to markets or customers

c. Labor

d. Proximity to suppliers.

e. Proximity to public transport facilities.

In addition for the potential of growth, important factors is 7 surrounding socio-economic characteristics, traffic flow, the cost of land, area regulations and public transportation. Community is the availability of people in an area to accept the consequences of both positive and negative rather than the establishment of a place of business in the area, whether the establishment of the business in that area.

Handoko (2000) mentions factors that generally need to be considered in choosing the location of the company, are as follows:

a. Environmental Society, the availability of a local community to accept all the consequences, both positive and negative consequences of the establishment of a plant in the area is an important requirement. Companies need to pay attention to the values of the 
environment and ecology in which the company will be located, as factories often produce waste in various forms of water, air, or waste solids that has been polluted, and often come with noise. On the other hand, people need the industry or the company as it provides jobs and money that brought the industry to the public. Good community environment for life of employees and executives also allows them to do a better job. Availability of school facilities, recreation, cultural activities and sports is an important part of this decision.

b. Proximity to the market. Close to market will enable companies to provide better service to the customer, and often reduce distribution costs. To consider also whether the company's market area or only serve a small portion of society, perishable products or not, weight distribution costs of products and the proportion of the total cost of finished goods. Large enterprises with a wide range of markets, can be set up factories in many places to approach the market.

c. Labor. Wherever the location of the company, should have a workforce, because it was pretty availability of labor is fundamental. For many companies now habit and attitude of prospective employees an area more important than skills and education, because it is rare companies that can find new workers who have been ready for the varied work and the level of specialization is very high, so the company must conduct an exercise program specifically for new employment. The people of the region can be a labor of better than from other regions, as reflected in the different levels of absenteeism and employee morale. In addition, withdrawal of labor, the quantity and distance, prevailing wage rates, as well as competition between companies in getting high-quality workforce, to note the company.

TABLE I. THE FACTORS CAN INFLUENCE THE SELECTION OF A BUSINESS LOCATION

\begin{tabular}{ll}
\hline \multicolumn{1}{c}{ Factor } & \multicolumn{1}{c}{ Research/Books } \\
\hline Proximity to consumers & Schemenner (1994), Chase et all (2006), Handoko (2000) \\
Proximity to schools / universities & O’Mara (1999) \\
Proximity to housing / residential & Schemenner(1994), Assauri (1980) \\
Proximity with competitors & Schemenner (1994), Alcacer (2004), Tjiptono (2007), Handoko (2000) \\
Ability equipment / supplies business & Schemenner (1994) \\
The existence of adequate parking space & Schemenner (1994), Tjiptono (2007) \\
Complete infrastructure & O’Mara (1999), Kuncoro (2003), Assauri (1980), Chase et all (2006) \\
Proximity to suppliers & Chase et all (2006), Handoko (2000) \\
The amount of tax & Chase et all (2006), Handoko (2000) \\
Proximity to road & Schemenner (1994) \\
The level of security & Handoko (2000) \\
Rents of business & Schemenner (1994), Assauri (1980), Handoko (2000) \\
\hline
\end{tabular}

d. Proximity to raw materials and suppliers. If the raw material weight and shrinkage is large enough in the production process, the company is better located near raw materials, such as cement, wood, paper, and steel. But when the finished product is heavy, bulky and of low value, then the location of selected instead. So also when the raw material quickly broken, such as company fruits in cans, preferably close to the raw material. Closer to raw materials and providers (suppliers) enables a company get a better supplier service and cost-saving procurement of materials.

e. Facilities and transportation costs. The availability of good transportation facilities by land, air and water to launch the procurement of the factors of production and distribution of the company's products. Consideration the importance of transportation costs depend "contribution" to the total cost, for example computer company transportation costs only about $1 \%$ or $2 \%$ of the total cost, it does not matter wherever the location of the company is compared to a cement company. For many companies the cost difference is not as important differences transportation labor costs. But, however, transportation costs can not be eliminated wherever the company is located, because the company had to be channeled from the raw material producer to the enduser; so, the facility should be located between the source of raw materials and markets to minimize transportation costs. Close to the raw materials will reduce the cost of transporting the finished product shipments increased. Instead, the location is close to the market will save the cost of transporting the finished product, but to raise the cost of transporting raw materials.

f. The others resources. Companies such as paper mills, steel, rubber, leather, sugar, weaving, food processing, Aluminum and so is in need of water in large quantities. Besides almost every industry requires both power generated from electricity, diesel, water, wind and others. Therefore, it should be noted the availability of natural resources with cheap and sufficient.

A company is also pleased adjacent to its competitors. An entrepreneur must identify the number and size of other businesses as well as the competitive situation existing in the area. Here are the factors that can influence the selection of a business location showed at Tabel 1 .

\section{Research Accomplished}

The previous study is the result of research that has been done previously associated with research that will be done by the author of the site selection. The studies that have been done before is as Tabel 2 . 
TABLE II

THE PREVIOUS STUDY

\begin{tabular}{|c|c|c|c|}
\hline No. & Research Topic & Method & Result \\
\hline 1 & $\begin{array}{l}\text { Business Location and } \\
\text { Success: The Case of } \\
\text { Internet Café in } \\
\text { Business in Indonesia. }\end{array}$ & $\begin{array}{l}\text { Using factor analysis and } \\
\text { regression analysis to analyze } \\
\text { the influence of the factors of } \\
\text { site selection for the success } \\
\text { of the business. }\end{array}$ & $\begin{array}{l}\text { By using the mean rating, there are five factors the selection of the } \\
\text { location of the key considerations, namely the availability of ISP } \\
\text { (internet service provider) adequate, proximity to customers, } \\
\text { security, availability of adequate infrastructure, and business } \\
\text { environment. From the results of the regression analysis, there are } \\
\text { three factors that have the most impact on the success of the } \\
\text { business, the availability of infrastructure, proximity to schools / } \\
\text { universities, and security. }\end{array}$ \\
\hline 2 & $\begin{array}{l}\text { Why Manufaturing } \\
\text { Industry Persisted to } \\
\text { Cluster Spatially in } \\
\text { Java, } \quad \text { Mudrajad } \\
\text { Kuncoro, 2003 }\end{array}$ & $\begin{array}{l}\text { Using regression analysis } \\
\text { with dummy variables. }\end{array}$ & $\begin{array}{l}\text { By using the mean rating, there are five factors the selection of the } \\
\text { location of the key considerations, namely the availability of ISP } \\
\text { (internet service provider) adequate, proximity to customers, } \\
\text { security, availability of adequate infrastructure, and business } \\
\text { environment. From the results of the regression analysis, there are } \\
\text { three factors that have the most impact on the success of the } \\
\text { business, the availability of infrastructure, proximity to schools / } \\
\text { universities, and security. }\end{array}$ \\
\hline 3 & $\begin{array}{l}\text { The Relationship } \\
\text { Between Supplier } \\
\text { Partnership, } \\
\text { Environmental } \\
\text { Variables and Firms } \\
\text { Performance in Retail } \\
\text { Industry, Agus } \\
\text { W.Soehadi, 2003 }\end{array}$ & $\begin{array}{l}\text { Using SEM (Structural } \\
\text { Equation Modeling). }\end{array}$ & $\begin{array}{l}\text { The results showed a relationship with a supplier positive effect on } \\
\text { company performance. }\end{array}$ \\
\hline 4 & $\begin{array}{l}\text { Strategic Drivers of } \\
\text { Location Decisions for } \\
\text { Information-Age } \\
\text { Companies, Martha } \\
\text { A.O'Mara, 1999 }\end{array}$ & $\begin{array}{l}\text { Using sociological research } \\
\text { refers to the "grounded } \\
\text { theory" which emphasizes } \\
\text { the use of inductive } \\
\text { reasoningyang can be } \\
\text { equated with empirical } \\
\text { research. }\end{array}$ & $\begin{array}{l}\text { The results showed the availability of infrastructure, availability of } \\
\text { labor and adequate infrastructure affect the choice of location. The } \\
\text { study also suggests future trends and their implications for the real } \\
\text { estate company's strategy and economic developments in selecting } \\
\text { a business location. }\end{array}$ \\
\hline
\end{tabular}

\section{Conceptual Frame Work}

\begin{tabular}{|c|c|}
\hline & Entrepreneurs Perceptions \\
\hline \multirow{5}{*}{$\begin{array}{l}\text { Business } \\
\text { Location } \\
\text { Village } \\
\text { Bakpia } \\
\text { Pathok }\end{array}$} & Factors Affecting the \\
\hline & Business location \\
\hline & determining: \\
\hline & 1. Community \\
\hline & Environmental \\
\hline & 3. Labor \\
\hline & 4. Proximity With Raw \\
\hline & Materials / Supplier \\
\hline & 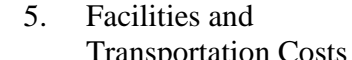 \\
\hline & 6. Resources (Natural) \\
\hline & more \\
\hline & (Handoko, 2000: 67-69) \\
\hline
\end{tabular}

Fig. 4. Conceptual Frame Work

\section{METHODS}

The research is used descriptive research methods that conducted with the main objective to create a picture or a description of a situation objectively. The unit of analysis of this study are entrepreneurs Pathok bakpia village, Village Ngampilan, District Ngampilan, Yogyakarta.
Likert scale is a tool to measure attitudes, opinions and perceptions of a person or a group of social phenomenon (Sugiyono 2014: 93). Each item instrument that uses a Likert scale has a gradation from very positive to very negative, which may include words such as:
a. Strongly agree
b. Agree
c. Doubtful
d. Disagree
e. Strongly Disagree

There are 2 Sub Variable :

a. Characteristics Biography

1) Sex

2) Age

3) Education

4) The number of workers

b. Perception Factors Affecting the Busines Location Determination :

1) Community Environment

2) Proximity to market

3) Labor

4) Proximity to raw materials and supplier

5) Facilities and transportation costs

6) The other resources 
Sampling technique used purposive sampling if researchers have certain considerations in setting an example according to the purpose of the research. Population in this study is the bakpia stock holders in Pathok village, where, according to data from the Village Ngampilan the end of 2014, there are 85 known brands in the village bakpia Pathok. Using of formula slovin the population number is 85 , so in this study takes as many as 68 samples.

\section{RESUlt AND Discussion}

\section{History of Bakpia}

Historically bakpia is food "imports" from China brought by Chinese immigrants in the early decades of the 20th century. This Bakpia have existed since 1930. It is owned by the families of many Chinese traders who occupies the center of Yogyakarta. (Exploring Jogja, issue 7).

Changes bakpia can be commercially linked to the historical context of the physical revolution. This assumption appears from the information that there is one bakpia factory was established in 1948 (Bakpia 75). In the political history of Indonesia, coinciding with the year 1948 when the Dutch military aggression II to Indonesia. A special area of Yogyakarta happen anyway guerrilla actions led by General Sudirman. The Indonesian economy is the Revolution (19451950) experienced difficult times.

\section{Bakpia Industry}

Bakpia industry is a small-scale business units are located in a village that no longer make agriculture as the backbone of the economy of the people. Economic activity outside the agriculture is closely linked to urban culture oriented entrepreneur.

When viewed from the perspective of institutions, bakpia belonging to the domestic industry. Industries which rely on efficiency and labor.

Based on data from the Central Bureau of Statistics in 2014, the highest type of industry in the district is the food industry, especially Ngampilan bakpia industry, a leading industry in the district Ngampilan.

In this section outlined and explained about the results of the research that has been done and processed to determine the factors in determining business location in the village bakpia Pathok.68 questionnaire has been granted and is completed by the respondents where they were entrepreneurs in the village bakpia Pathok. Profile of respondents were asked in the questionnaire are gender, age, education, past and number of entrepreneurs. Here is the data obtained about the profile of the respondents.

\section{Validity of Test Results}

Test will test the validity of each variable used in this study, in which all variables the study contains 18 questions to be answered by the respondent. The criteria used in determining whether or not valid questions used in this study are as follows:

Significant level $($ confidence level $)=95 \%(\alpha=5 \%)$.
Degrees of freedom $(\mathrm{df})=\mathrm{N}-2=30-2=28$; the importance of the table $r=0.31$ which is $r$ counted value 0.60

\section{Realibility of Test Result}

Reliability testing results shows that the value of Cronbach's Alpha has a coefficient greater than 0.60. Thus be concluded that the measuring instruments used in this study is reliable.

TABLE III. RELIABILITY STATISTICS

\begin{tabular}{lr}
\hline \multicolumn{1}{c}{ Cronbach's Alpha } & N of Items \\
\hline .838 & 18 \\
\hline
\end{tabular}

\section{Descriptive Analyisis}

\section{A. Community environmental}

Perceptions regarding Pathok village entrepreneurs in business support community environmental indicators bakpia get the mean value is 3.99. While indicators of entrepreneurs feel disadvantaged by the many similar efforts to get a mean value of 3.85. Then the overall mean value of the subCommunity Environment variables are: $(3.99+3.85) / 2=3.92$

Based on the above data it can be seen that the environmental community to get the highest mean of 3.92. In other words, society is a factor of the business location of the most dominant in the perception of entrepreneurs in the bakpia village. Locations facilitate mutual trust and a good relationship between small businesses, between workers and skill labor. According to Mr. Ridwan Effendi, chairman of the community of Laris Manis, development of business in the village Pathok bakpia can be attributed to the efforts bakpia first in Yogyakarta, namely bakpia with brand 75.Bakpia 75 has several employees from around the location and then some workers opened his own business. Some business that residents in the village began Pathok view and are interested in opening their own businesses with the hope bakpia a better economic life. Mr. Ridwan himself claims will continue to encourage residents in the village who want to open a business Pathok bakpia. Many entrepreneurs who claim expertise makes their bakpia from teaching their neighbors. Look in potential, many citizens who later switched professions become bakpia businesses.

\section{B. Proximity By Market}

Perceptions of entrepreneurs about Pathok village in affordable business location indicator to get a mean value of 3.63. While the biggest buyer immediately came to the scene to get a mean value of $3: 49$, and the perception of the product durable bakpia not get a mean value of 3:09. Then the overall mean value of the sub-variable proximity of the market are:

$$
(3.63+3.49+3.09) / 3=3.40
$$

Based on the above data it can be seen that the proximity to the market was the mean value of 3:40. Then we can say a lot of entrepreneurs who agree with the statement on sub-variables closeness to the market. This can be attributed to the location of the village Pathok conveniently located in the city center and 
within walking distance of several tourist attractions. Some entrepreneurs who answered disagree in general has other marketing strategies, for example with a system entrusted selling to places like stations, terminals, a souvenir shop, and the location of nearby attractions, so that proximity to the market which is the weakness of the business can be deal with distribution system which allows.

\section{Labor}

Perceptions of entrepreneurs about Pathok village in making expertise indicator bakpia of family (hereditary) mean value of 3.12. While having worked in the industry bakpia get the mean 2:53, and indicators of the employees live in the area of business location to get a mean value of 2:57. Then the overall mean value of the sub-variables of Labor is:

\section{$(3.12+2.53+2.57) / 3=2.74$}

Based on the above data can be known that the subvariables of Labour scored a mean of 2.74. This value is the lowest score in the study, which means that many entrepreneurs who do not agree with statements on the subvariable power Pathok worker. Entrepreneurs village hired many employees who come from outside the region, as evidenced by the majority of respondents who disagree employees live in the vicinity of work. besides, most respondents claimed membership making bakpia is not come from a family or industry. It is makes weak assessment of the sub-variable labor.

\section{Proximity With Raw Materials / Supplier}

Perceptions of entrepreneurs about Pathok village in the indicator purchase raw materials around the site gets a mean value of $4: 12$. while having suppliers specifically obtain the mean value is 3.94 and there is a shrinking process heavy when production obtain a mean value of 2.65 . Then the overall mean value of the sub-variable Closeness With Raw Materials / Supplier are:

$$
(4.12+3.94+2.65) / 3=3.57
$$

Based on the above data that sub-variables proximity to raw materials and suppliers obtain the mean value of 3:57. This figure means that many respondents were positive rate business location within walking distance of the raw material / supplier. The raw materials is a factor to consider in determining the location. The ease in obtaining raw materials will support the smooth process of production and other business activities. Near the village layout Pathok located in the city center benefits entrepreneurs in obtaining raw materials production. Bakpia raw materials is also not a seasonal item, such as green beans, flour, sugar, salt and oil, including the categories of goods are easily available in the market.

\section{E. Facilities and Transportation Costs}

Perceptions of entrepreneurs about Pathok village in the indicator in cooperation with a party to bring buyers to the site to get a mean value of 3:40. While there are public transport facilities to reach locations to get mean $3: 19$, and easily distribute goods to the store got a mean value of $3: 46$. Then the overall mean value of the sub-variables Facilities and Transportation Costs are:

$$
(3.40+3.19+3.46) / 3=3.35
$$

Based on the above data it can be seen that the subvariables of facilities and transportation costs to get the mean value of 3:35, which means entrepreneurs positive rate in the sub-variable location facilities and transportation costs. Transportation is often found in the area between the villages Pathok another carriage, rickshaw, rental cars and tour buses. For public bus transportation routes not served directly to the village Pathok.

\section{F. Resources (Natural) Other}

Perceptions regarding Pathok village entrepreneurs in the indicators of electricity, water and gas easily obtained to get a mean value of 3.79 and problem is none of the resources that inhibit the production earn a mean value of 3.82 . Then the overall mean value of the sub-variable Resources (Natural) Others are:

$$
(3.79+3.82) / 2=3.81
$$

Based on the above data it can be seen that the sub-variable other resources get the mean value of 3.81 , as well as the second highest factor in business location factors in this study. Higher values mean in the sub-variable other resources means that entrepreneurs have no difficulty obtaining it that are used in the production process, especially electricity, water and gas. Other resources is a factor that must be considered in determining the location of the business because it is an important component in the industrial business, the non existence may hamper the production process.

\section{CONCLUSION}

Based on all the factors determining the location of businesses surveyed in this study are community environment, the resources (natural) more resources, proximity to raw materials/suppliers, the proximity by the market, facilities and transportation costs, the Labor/manpower.

The most dominant factor in determining business location in the village bakpia Pathok is Communities Factor according to the perceptions of entrepreneurs.

Based on the lowest score the conclusion are, the entrepreneurs and government must continue and enhance good relations with the owners bakpia such a dialogue, production or management training, as well as the design of programs that support the advancement of industry bakpia centers in Pathok village, Yogyakarta.

\section{REFERENCES}

Akhmad, K. (1996). Manajemen Investasi. Jakarta :Rineka Cipta. Buchari, Alma. 2003.Manajemen Penjualan dan Pemasaran asa, Bandung :Alfabeta.

Alwi, H. (2007). Kamus Besar Bahasa Indonesia. Jakarta: Balai Pustaka. 
Ghozali, Imam. (2005). Aplikasi Analisis Multivariate dengan Program SPSS. Semarang : Badan Peneribit UNDIP

Handoko, T. H. (2000). Dasar-Dasar Manajemen Produksi dan Operasi Edisi I. Yogyakarta: BPFE.Heizer, Jay dan Render Barry. 2004. Manajemen Operasi. Jakarta :Salemba Empat.

Indarti, Nurul. 2004. "Factors Affecting Entrepreneurial Intentions".

Ismail, S. (2011). "Pola Kampung Dan Rumah Tinggal Warga Desa Masyarakat Adat Sunda"

Kuntjoro, M. (1996). "Struktur dan Kinerja Indonesia Setelah 50 tahun Merdeka :Adakah Peluang Usaha Kecil?", Jurnal Ekonomi, tahun II, vol.7, Januari.

Kusmayadi. (2000). Metode Penelitian dalam Bidang Kepariwisataan. Jakarta: PT. Gramedia Pustaka Utama.

Lamb et.al. (2001). Pemasaran Edisi Pertama. Jakarta: Salemba Empat

Laporan Akuntabilitas KinerjaInstansi Pemerintah (LAKIP) Direktorat IKM Wilayah II Tahun Anggaran 2014 oleh Kementerian Perindustrian RI.diakses melalui www.kemenperin.go.id

Laporan Disperindagkoptan DIY 2012 tentang IKM dan potensinya.Daerah Istimewa Yogyakarta diakses melalui disperindagkop.jogjaprov.go.id

Laporan Survey LapanganKajianStandarNasional Indonesia ProdukUnggulan UKM Sektor Pangan Kota Yogyakarta 2012.

Manullang, M. (2001). Manajemen Sumber Daya Manusia, Edisi1.Yogyakarta: BPFE.
Modul Diklat Teknis Sistem Industri Aparatur, (2010) diakses melalui bps.go.id

Pratiwi,A. (2010) .’Faktor-Faktor Yang Mempengaruhi Pemilihan Lokasi Terhadap Kesuksesan Usaha Jasa"

Priyanto, Sandjojo. (2005). "Dinamika Pembelajaran Kewirausahaan Pada UKM"

Rakhmat, J. (2007). Persepsi Dalam Proses Belajar Mengajar.Jakarta :Rajawali Pers.

Ricklefs, M.C. (2005). Sejarah Indonesia Modern 1200-2004 (Terjemahandari "A History of Modern Indonesia Since c.1200 Third Edition”). Jakarta: SerambiIlmuSemesta.

Santoso, A., Widowati, S.. (2011). Pengaruh Kualitas Pelayanan, Fasilitas dan Lokasi terhadap Keputusan pembelian. Jurnal Dinamika Sosial Budaya, No. 2, FEUSM.

Setiawan, G. (2004). Implementasi Dalam Birokrasi Pembangunan.Jakarta :Cipta Dunia.

Sofa, H. 2008.Teori Lokasi.

Sudarman, dkk. (1993). Kamus Cina-Mandarin. Surabaya: Apollo

Sugiyono. (2014). Metode Penelitian Kuantitatif Kualitatif dan R\&D. Bandung : Alfabeta.

Suharman. (2005). PsikologiKognitif. Surabaya : Srikandi.

Sunaryo. (2004). Psikologi Untuk Keperawatan. Jakarta : EGC.

Suwarman, U. (2004). Perilaku Konsumen. Jakarta : Ghalia Indonesia.

Tjiptono, F. (2002). Strategi Pemasaran. Yogyakarta :Andi. Walgito. (2004). Psikologi Umum. Yogyakarta : Andi.105 